The Canadian Journal of Higher Education, Vol. XXIII-2, 1993

La revue canadienne d'enseignement supérieur, Vol. XXIII-2, 1993

\title{
Gender Issues in University: The University As Employer Of Academic And Nonacademic Women And Men
}

\section{E. DIANNE LOOKER ${ }^{*}$}

\begin{abstract}
This paper examines data from a small university in Atlantic Canada, focusing on the university as employer, in order to highlight one asf-ect of the impact of gender on universities. The data include official records on all employees, details from contracts and terms of employment, responses to questionnaires sent to all employees, and unstructured interviews conducted with university officials. Employees belong to one of six groups: faculty, librarians, professional and technical workers, secretarial-clerical workers, physical plant employees, and "non- classified". Working conditions and salaries vary across groups and within groups by step, rank or level. Women employees are concentrated in the secretarial-clerical group, one of two with restrictive working conditions. Women are more likely than men to be part-time employees, with few employee benefits. Men dominate the higher ranks of each group; women are concentrated at the lower ranks. Regression analyses of salaries show that, even with controls for rank, seniority and education, women in each employee group tend to earn considerably less than their male colleagues. Responses to the questionnaire reveal that women report more gender discrimination and sexual harassment than do men. The analysis highlights the importance of developing structures to address issues of gender equity for all university employees.
\end{abstract}

* Department of Sociology, Acadia University. The author would like to acknowledge the funding provided by her University for the study reported in this paper, and the support and encouragement provided by Dr. M. Conrad, the Status of Women Committee, and other interested individuals. 


\section{Résumé}

Ce article présente les données provenant d'une petite université des Provinces de l'Atlantique et examine l'Université en tant qu'employeur par rapport à un aspect de l'impact du sexe sur les universités. Les données incluent des informations extraites des dossiers officiels sur les employés-es, des détails sur les contrats de travail et les conditions d'emploi, des réponses aux questionnaires distribués à tous les employés-es et des résultats des entrevues non-structurées effectuées auprès des cadres de l'Université. Les employés-es sont catégorisés-es en six groupes: professeurs, bibliothécaires, travailleurs professionnels et techniques, secrétaires et/ou employés-es de bureau, employés-es du bâtiment et autres employés-es non-classé-es. L'étude montre que les conditions de travail et de salaire varient d'un groupe à l'autre et, à l'intérieur des groupes, par échelon, rang et niveau. Les employées de sexe féminin se concentrent dans le groupe des secrétaires et/ou des employés-es de bureau, une sur deux ayant des conditions de travail limitées. Les femmes, plus quel les hommes, occupent des employés à temps partiel bénéficiant d'avantages sociaux limités. Les hommes dominent les rangs les plus élevés de chaque groupe d'emploi; les femmes se concentrent dans les rangs les plus bas. Les analyses de régression sur le salaire montrent que même en contrôlant pour le rang, l'ancienneté et l'éducation, les femmes dans chaque groupe d'emploi ont tendance à gagner considérablement moins que leurs collègues masculins. Les réponses aux questionnaires révèlent également que les femmes rapportent davantage de situations de discrimination selon le sexe et de harcèlement sexuel que les hommes. Les analyses soulignent donc l'importance de développer des structures appropriées pour traiter des questions d'équité d'emploi concernant tous les employés de l'Université.

There has been considerable interest in the university as employer, especially as an employer of faculty. However, in order to get a more complete picture of employer policies we must consider the position of non-academic employees as well. This paper will examine data from one case study of a small university in the Atlantic region to compare and contrast the treatment of academic and nonacademic employees.

Many studies have been undertaken to examine the status of women at different institutions (see references). These reports document a discouragingly consistent picture of women faculty being at a disadvantage when compared to their men colleagues. In this comparison of faculty with other employees, particular attention will be paid to the position of women, in order to examine 
whether the situation that has been documented for faculty exists for the non-academic staff as well.

The same individuals in the senior administration set the policies for all employees and create the climate in which women and men employees work. As Backhouse et al. (1989) document for the University of Western Ontario, this is often a very "chilly climate" for women. Including the non-academic staff in the analysis highlights the irony of the situation of many women employees. Despite their large numbers (a majority at the institution examined in this study) women are marginalized into the less visible and less powerful positions. Status of women reports from many universities have documented the marginalization of women faculty. This study will present data to show that both women and men faculty have several advantages over their non-academic co-workers. Within each category, however, women are consistently disadvantaged relative to men.

\section{Description of the Data}

There are four separate data files that will be used for this case study. Two of these are drawn from the official personnel files of faculty and other staff. These files contain data on the employee's position, type of employment, grade or rank, and salary. Most of the analyses reported below are based on these official data. Other data come from a survey of all employees, done in 1986-87, which asked about working conditions, union involvement and perceptions of discrimination. Some supplementary information is also taken from the formal or informal collective agreements for the different groups of employees. Unless otherwise indicated, all the data refer to the academic year, 1986-87.

Official personnel data were obtained for virtually all individuals who were employed at this institution in the academic year 1986-87, including the senior administrators. The only exceptions were casual staff hired for less than two weeks, faculty who taught one course, and one individual whose faculty file was misplaced when he became a member of the non-academic staff. The survey was undertaken on behalf of the university's status of women committee, with the support of the university administration. After pretesting of the data instruments, questionnaires were sent to all faculty and staff in early 1987. Reminder letters and a second copy of the questionnaire were sent to nonrespondents. The final response rates for the questionnaires were $71 \%$ for faculty and $53 \%$ for the non-academic staff.

The response rates were particularly low for employees working in the physical plant. Their response rates to surveys from the university administration 
are typically lower than for other groups. In this instance, the rates were depressed further by the fact that the surveys were distributed at a time when some contentious negotiations for a new contract were underway. Also, some non-respondents told the researcher that they feared they could be identified since the survey included detailed questions about their position.

It is important to note that no tests of statistical significance are calculated in this analysis. The data set can be seen as either a total population (of employees at this institution in 1986-87), or a non-random sample across time of one year. Neither of these interpretations justifies the use of tests of statistical significance. The differences between men and women discussed in detail in the text are large enough to meet the criteria of substantive (as well as statistical) significance.

The employees fall into six categories or groups: (1) faculty, (2) librarians, (3) those in professional or technical positions (who are subclassified into four, hierarchically arranged subgroups), (4) those in secretarial or clerical positions, (5) physical plant workers and (6) those whom the personnel office refers to as "nons," who are not in any of these five categories. The "nons" include a lot of part-time employees, such as library assistants and summer workers, as well as the senior administrators and some others who report directly to a vice president or higher. The "physical plant" group has three sub-groups with different contractual arrangements: (a) the steam plant engineers, (b) those in skilled trades and maintenance, and (c) those in "housekeeping" (custodians and laundry workers).

In 1989 a new category of "senior manager" was created, comprised of thirteen men who report directly to the president or to a vice-president. The positions included were: the Directors of Admissions and Student Assistance, Alumni Services, Information Services, Development, Personnel, Physical Plant, Security, Student Services, the Computer Centre, as well as the Comptroller, Registrar, University Librarian and University Chaplain. Some of these had been "non;" others were at the highest level of the professional-technical group in 1986-87.

Faculty, the three physical plant sub-groups, and the secretarial-clerical staff have formal collective agreements recognized under the provincial trade union legislation. The librarians, and the professional-technical staff have informal but written agreements that spell out duties and responsibilities. The "nons" have no corresponding document. For the part-time and casual staff among the "nons," this tends to mean there is no room for negotiation. They are paid at or close to the minimum wage and have no job protection or benefits. For the high 
status "nons", the lack of any formal document means that they have considerable flexibility in negotiating their individual salaries, working conditions and job duties. As is true with any such organization, the highest ranking administrators are themselves employees, but they are also charged with the responsibility of setting employment policies on behalf of the Board of Governors. They are both employers and employees.

\section{Employees and Their Working Conditions}

The university being examined is small; the student body ranges from 3000 to 3500. There are only 268 faculty, 217 men and 51 women. There are considerably more non-academic staff, 478 at the time of the data collection. What is more, over half $(52 \%)$ of the non-academic staff are women. Despite a common image that universities are predominantly male institutions, there are more women than men among the non-academic staff, and there are more women among the non-academic staff than there are men faculty.

Although they are all employed by the same organization, there are quite different terms of employment set out for the different groups of employees. Trying to get an accurate picture of the various sets of conditions for employees is complicated by the fact that the composition of these groups changes, as do the terms of employment as new negotiations are completed. The terms for the different groups change at different times and in different ways. All one can do is get a snapshot of conditions at one time, recognizing that some details of the descriptions may be made inaccurate before the description is even published. Nevertheless, the gender differences, reported below, have been in place for over fifteen years, and are not likely to be affected by these minor shifts.

The working conditions of employees very much depend on the employee group to which they belong. A comparison of the terms of employment for the different groups and sub-groups documents the fact that benefits are distributed in an explicitly hierarchical fashion. Certain groups, especially faculty and librarians, have more generous provisions and more flexible arrangements, while others, especially physical plant and secretarial-clerical workers are more restricted. This hierarchy is explicitly written into the terms of employment for the professional- technical employees; sub-groups 1 and 2 have much more restrictive working conditions than do subgroups 3 and 4.

Sick leave provisions vary among the different employee groups (see Table 1A). Physical plant workers are entitled to one and half days per month, up to a maximum accumulation of 130 days. Secretarial-clerical workers, and those in the lowest two subgroups of the professional-technical staff get one and three 
Table 1A

Selected Benefits. Five Employee Groups

\section{Employee group}

\begin{tabular}{|c|c|c|c|c|c|}
\hline Benefits & $\begin{array}{l}\text { Physical } \\
\text { Plant }\end{array}$ & $\begin{array}{c}\text { Secretarial } \\
\text { Clerical }\end{array}$ & $\begin{array}{l}\text { Professional } \\
\text { Technical }^{2}\end{array}$ & Librarians & Faculty \\
\hline Sick Leave & $\begin{array}{c}1 \& 1 / 2 \\
\text { days per } \\
\text { month }\end{array}$ & $\begin{array}{c}1 \& 3 / 4 \\
\text { days per } \\
\text { month }\end{array}$ & $\begin{array}{c}\text { S1+S2:- } \\
1 \& 3 / 4 \text { days } \\
\text { per month } \\
S 3+S 4:- \\
6 \text { months }\end{array}$ & 6 months & 6 months \\
\hline
\end{tabular}

\begin{tabular}{|c|c|c|c|c|c|}
\hline $\begin{array}{l}\text { Vacation } \\
\text { Allowance }\end{array}$ & $\begin{array}{l}\text { <1 year: } \\
1 \text { day/mo } \\
\text { 1-2 years: } \\
2 \text { weeks } \\
2-10 \text { years: } \\
3 \text { weeks } \\
\text { 10-20 years: } \\
4 \text { weeks } \\
>20 \text { years: } \\
5 \text { weeks }\end{array}$ & $\begin{array}{c}\text { <1 year: } \\
1 \text { day/mo } \\
1-2 \text { years: } \\
10 \text { days } \\
2-10 \text { years: } \\
15 \text { days } \\
10-20 \text { years: } \\
20 \text { days } \\
>20 \text { years: } \\
25 \text { days }\end{array}$ & $\begin{array}{c}\text { see } \\
\text { Table 1B } \\
\text { below }\end{array}$ & $\begin{array}{c}22 \text { days } \\
(+5 \text { days } \\
\text { after } \\
20 \text { years })\end{array}$ & 1 month \\
\hline $\begin{array}{l}\text { Bereavement } \\
\text { leave }\end{array}$ & tt 5 days & 3 days & 3 days & $\begin{array}{c}\text { No } \\
\text { specified } \\
\text { limit }\end{array}$ & $\begin{array}{c}\text { No } \\
\text { specified } \\
\text { limit }\end{array}$ \\
\hline $\begin{array}{l}\text { Maternity } \\
\text { leave }\end{array}$ & $\begin{array}{c}\text { Unpaid } \\
\text { leave + } \\
\text { U.I.C. }\end{array}$ & $\begin{array}{l}\text { Unpaid } \\
\text { leave + } \\
\text { U.I.C. }\end{array}$ & $\begin{array}{c}\text { Unpaid } \\
\text { leave + } \\
\text { U.I.C. }\end{array}$ & $\begin{array}{l}\text { Full pay } \\
12 \text { weeks }\end{array}$ & $\begin{array}{l}\text { Full pay } \\
12 \text { weeks }\end{array}$ \\
\hline $\begin{array}{l}\text { Paternity } \\
\text { (for birth) }\end{array}$ & 8 hours & 1 day & 1 day & $\begin{array}{c}\text { No } \\
\text { specified } \\
\text { limit }\end{array}$ & $\begin{array}{c}\text { No } \\
\text { specified } \\
\text { limit }\end{array}$ \\
\hline $\begin{array}{l}\text { Prescribed } \\
\text { Breaks }\end{array}$ & $2 \times 10 \mathrm{~min}$ & $2 \times 15 \mathrm{~min}$ & $\begin{array}{c}\mathrm{S} 1+\mathrm{S} 2 \\
2 \times 15 \mathrm{~min} \\
\mathrm{~S} 3+\mathrm{S} 4 \\
\text { No specified } \\
\text { limit }\end{array}$ & $\begin{array}{l}\text { No } \\
\text { specified } \\
\text { limit }\end{array}$ & $\begin{array}{l}\text { No } \\
\text { specified } \\
\text { limit }\end{array}$ \\
\hline
\end{tabular}

a Differences for subgroups indicated where S1, S2, S3, S4 stands for subgroups 1 through 4 
Table 1B

Vacation Provisions, Subgroups, Professions-Technical Employees

\begin{tabular}{|c|c|c|c|c|}
\hline \multirow{2}{*}{$\begin{array}{l}\text { Vacation } \\
\text { Entitlement }\end{array}$} & \multicolumn{4}{|c|}{ Service Requirement } \\
\hline & Subgroupl & Subgroup 2 & Subgroup 3 & Subgroup 4 \\
\hline 10 days after & 1 year & $\ldots . .$. & ----- & ----- \\
\hline 15 days after & 2 years & 1 year & ----- & ----- \\
\hline 20 days after & 10 years & 10 years & 1 year & 1 year \\
\hline 25 days after & 20 years & 20 years & 20 years & 20 years \\
\hline
\end{tabular}

quarter days per month. The contract for the secretarial-clerical staff, but no others, has a provision that "excessive intermittent use of [sick leave] benefits may be considered as chronic absenteeism...". Librarians, faculty and those in the higher professional-technical subgroups are entitled to full pay for up to six months sick leave.

Vacation provisions are based on seniority for physical plant workers and the secretarial-clerical staff. Vacation entitlements for the professional-technical employees are based on a combination of sub-group rank and seniority. Librarians may take 22 days vacation, plus an additional 5 days after 20 years of service. A full-time faculty member is entitled to a month's vacation any time outside the fall-winter academic session.

There is provision for emergency leave for most employees. For physical plant workers this is restricted to two days, and is allowable only for "fire or flood in his [sic] home". Other employees have no prespecified restrictions on. the length of emergency or compassionate leave; for secretarial staff emergencies can include serious illness of a family member, as well as "fire or flood". There is no restriction on the type of emergencies that are considered for faculty or librarians.

Bereavement leave is provided for separately. Secretarial and professionaltechnical staff have up to three days, physical plant workers up to five days. No prespecified limits exist for faculty or librarians.

One set of benefits that particularly affect women includes provisions for maternity, paternity and adoption leave. The university provides paid maternity leave only for librarians and faculty, for a period of up to twelve weeks. Other full-time, non-probationary employees can be granted an unpaid leave of absence, during which time they are eligible for maternity benefits under 
unemployment insurance provisions. They are assured that they will be rehired at the same or a similar position once they return to work. Men in the physical plant are allowed eight hours leave during their wives' "confinement"; men in the secretarial-clerical and the professional-technical groups are entitled to one day's leave. Men who are faculty or librarians can apply for up to six weeks paternity leave if their "spouse, though currently employed, is unable to obtain paid maternity leave because of the employment policies in practice at her work place." Leave for a man who is a faculty member or librarian, in order to attend the birth of his child, would be provided for by his flexible schedule and the wide-ranging provision for emergency and/or compassionate leave. Adoption leave of up to four weeks without pay is available to employees, other than faculty or librarians who are eligible for six weeks with full pay.

Consistent with their definition as professionals, faculty and, to a lesser extent, librarians and those in the top sub-groups of the professional-technical staff, have considerable flexibility about when they have to be on campus. Other employees have designated hours, as well as prespecified times for lunch and breaks. Physical plant employees are paid on the basis of a forty hour work week; other non-faculty employees are expected to work thirty-five hours per week. No set hours are specified for faculty, librarians, senior managers or administrators who are expected to keep flexible hours and work overtime, without extra pay, as required by their job duties.

Physical plant workers are entitled to two ten minute breaks and a thirty minute lunch break; others have two fifteen breaks and an hour for lunch. Physical plant workers are the only ones who have to "punch in and out" with a time clock. They are allowed 8 minutes leeway per day. Beyond that, they are docked pay for each 15 minute period they are late, no matter what the reason. Heavy snowfalls with drifting make many roads impassable several times during the winter; the financial penalty for lateness would apply to any physical plant worker delayed by snow or other weather conditions.

Gender can affect benefits at least three ways. The first occurs when women (or men) are concentrated in positions that carry more restrictions than others. The second occurs when men and women are distributed at different levels, ranks or grades within a given group. A third results if one gender forms the majority of part-time employees, since part-time employees rarely share the benefits available to their full-time co-workers.

Table 2 shows the distribution of men and women across the broad employee groups. The first part of the table (Table $2 \mathrm{~A}$ ) gives the percentage of men and women in each group. Women make up $85 \%$ of the secretarial-clerical staff, 
Table 2A

Distribution of Employees by Gender in Each Group

\begin{tabular}{lrrcr}
\hline & Men & Women & \% Women & Total \\
\hline Physical Plant & 115 & 25 & $18 \%$ & 140 \\
Secretarial/Clerical & 20 & 111 & $85 \%$ & 131 \\
Professional & & & & \\
Technical $^{\text {* }}$ & 48 & 37 & $44 \%$ & 85 \\
Librarians $^{\circ}$ & 4 & 5 & $55 \%$ & 9 \\
Faculty & 217 & 51 & $19 \%$ & 268 \\
"Non" & 48 & 75 & $61 \%$ & 123 \\
\hline
\end{tabular}

a Includes senior managers

b Excludes the Head Librarian, classified as "Non".

Table 2B

Distribution of Employees by Group for Men and Women

\begin{tabular}{lrrr}
\hline & Men & Women & Total \\
\hline Physical Plant & $25 \%$ & $8 \%$ & $19 \%$ \\
Secretaria//Clerical & $4 \%$ & $37 \%$ & $18 \%$ \\
Professional $^{\text {Technical }}{ }^{2}$ & $11 \%$ & $12 \%$ & \\
Librarians $^{\circ}$ & $1 \%$ & $2 \%$ & $11 \%$ \\
Faculty $^{\text {NNon" }}$ & $48 \%$ & $17 \%$ & $1 \%$ \\
Total & $11 \%$ & $25 \%$ & $36 \%$ \\
\hline
\end{tabular}

a Includes senior managers

b Excludes the Head Librarian, classified as "Non". 
$61 \%$ of the "nons", $44 \%$ of the professional-technical group, 5 of the 9 librarians, $19 \%$ of faculty, and $18 \%$ of the physical plant workers. If one examines only full-time employees (data not shown) the percentage of women in the different groups changes somewhat, but the overall picture is still the same. Women are concentrated in the secretarial-clerical positions and form a minority in the faculty and the physical plant. The percentage of full-time employees who are women drops to $54 \%$ among the "nons" and to $42 \%$ among the professional-technical staff.

Table 2B shows the distribution across groups run separately for men and women. Faculty, physical plant and the secretarial-clerical groups are the three largest. Almost half (48\%) of the male employees are faculty; another $25 \%$ work in the physical plant. The largest concentrations of women are found in the secretarial-clerical group (37\%) and the "nons" (25\%).

There are some important gender differences within each of these groups as well. Table $3 \mathrm{~A}$ shows a pattern that is familiar to many of those who have examined the position of faculty women. Women dominate the lower ranks, (Lecturer and Assistant professor) while men dominate the higher ones. The picture has changed a bit since the time of this data collection. The distribution of men is almost identical in 1989-90 to what it was in 1986-87. The percentage of women who are full professors increased so that $21 \%$ of the 68 women in 1989-90 have attained this rank. At the other end of the scale, however, the proportion of women lecturers increased from $21 \%$ to $34 \%$ in that three year period. Both men and women among the secure, tenured faculty are moving through the ranks. Other faculty, especially women, are caught in the more tenuous, low level, contractually limited positions.

Half of all the men in the non-academic staff work in the physical plant. Two of the three subgroups of physical plant workers have no women: the steam plant engineers and those in trades and maintenance. The women are all in "Housekeeping", the classification with the lowest pay. Only one woman among the physical plant workers is a "foreman"; none of the five supervisors is a woman.

Among the librarians, the only differentiation takes the form of having administrative duties. The two Heads of Division are men, as is the University Librarian, who falls into the "non" grouping. This was not always the case. The Library is, in fact, one of the few areas of this university which have been headed by a woman.

The "nons" have no terms of reference and so no formal ranking scheme. The high level "nons" (the senior administrators, the university chaplain and the Head Coach of the football team) are all men. 
Table 3A

Gender by Rank or Level with Employee Group

3A Faculty

\begin{tabular}{lrc}
\hline & \multicolumn{2}{c}{ Sex } \\
\cline { 2 - 3 } Rank & Men & Women \\
\hline Full Professor & $36 \%$ & $10 \%$ \\
Associate Professor & $37 \%$ & $26 \%$ \\
Assistant Professor & $22 \%$ & $43 \%$ \\
Lecturer & $6 \%$ & $21 \%$ \\
Total & 202 & 42 \\
& & \\
\hline
\end{tabular}

Table 3B

Gender by Rank or Level with Employee Group

3B Physical Plant

\begin{tabular}{lrr}
\hline & \multicolumn{2}{c}{ Sex } \\
\cline { 2 - 3 } Level & Men & Women \\
\hline 1. Probationary & $15 \%$ & $8 \%$ \\
2. Nonprobationary & $71 \%$ & $88 \%$ \\
3. Foreman/Supervisor & $14 \%$ & $4 \%$ \\
Total & 113 & 24 \\
& & \\
\hline
\end{tabular}

Table 3C

Gender by Rank or Level with Employee Group

3C Librarians

Sex

Level

Men

Women

Head of Division

2

0

Other 
Table 3D

Gender by Rank or Level with Employee Group

3D Professional \& Technical-

\begin{tabular}{lrrrrr}
\hline & \multicolumn{5}{c}{ Subgroup } \\
\cline { 2 - 6 } Sex & 1 & 2 & 3 & 4 & Total \\
\hline \multirow{2}{*}{ Men } & $5 \%$ & $22 \%$ & $32 \%$ & $41 \%$ & 39 \\
Women & $13 \%$ & $45 \%$ & $39 \%$ & $3 \%$ & 38
\end{tabular}

* 1989-90 data, includes "senior managers"

Table 3E

Gender by Rank or Level with Employee Group

3E Secretarial Clerical

\begin{tabular}{|c|c|c|c|c|c|c|c|c|}
\hline \multirow[b]{2}{*}{ Sex } & \multirow[b]{2}{*}{2} & \multicolumn{7}{|c|}{ Grade } \\
\hline & & 3 & 4 & 5 & 6 & 7 & 8 & Total \\
\hline Men & $0 \%$ & $0 \%$ & $25 \%$ & $15 \%$ & $20 \%$ & $35 \%$ & $5 \%$ & 20 \\
\hline Women & $4 \%$ & $12 \%$ & $44 \%$ & $24 \%$ & $12 \%$ & $4 \%$ & $1 \%$ & 110 \\
\hline
\end{tabular}

The professional-technical group has eight "grades". Under their terms of agreement, these are collapsed into four sub-groups. Although women make up almost half of this group overall, Table 3D shows that they are concentrated at the lower end of the scale. Well over half of them $(13 \%+45 \%)$ are in the two lowest sub-groups, with the most restrictive benefits. Men outnumber women in the two highest sub-groups. This dominance of men at the higher ranks holds even when the men classified as senior managers are excluded; $46 \%$ of the 26 men left in this group are in subgroup 3,15\% are in sub-group 4.

The secretarial-clerical group is especially interesting, partly because $45 \%$ of the women with non-academic positions are in this group. As indicated above, over $80 \%$ of this group are women. Despite their large numbers and proportion, women do not "dominate" this group. Table $3 \mathrm{E}$ shows that, once again, women are clustered at the low end of the grade scale, with over half $(4 \%+$ $12 \%+44 \%$ ) of them in levels 2,3 or 4 . (In the mid 1980's "level 1" was eliminated from the grid, so the lowest remaining level is "level 2"). Only a quarter 
of the few men in this group have such a low grade level, and these individuals are all at level 4 . At the other end of the scale, there is a higher percentage of men than women; what is more, the men outnumber the women $(8 \mathrm{men}$ and 5 women are in the two highest grades).

Not only are women more likely to be in certain groups, they also make up more than half of the part-time employees. Half of all the 154 part-time workers are classified as "nons", and $50(64 \%)$ of these 77 "nons" are women. All of the part-time secretarial- clerical workers are women. While part-time men faculty outnumber their women counterparts ( 26 men versus 15 women), this ratio reflects the male dominance of the faculty positions overall. Proportionately more women than men are in part-time faculty positions. Men dominate parttime as well as full-time positions in the physical plant. There are no part-time librarians.

The distinction between full and part-time employees has a dramatic impact on access to benefits. Part-time employees have no job security, no pension benefits, limited or no sick leave provisions. Not surprisingly they also have lower salaries than those in full-time positions.

To summarize this section: there is gender segregation among the university employees along several dimensions. Women are more likely to be in certain categories of employees (especially the secretarial-clerical and the "nons"), while men are concentrated in others (faculty and physical plant). Within each group, even the ones dominated by women, women are more likely to be at the lower grades or ranks, while men dominate the higher levels. There is also a gender difference in the type of employment. Men are more likely than women to have full-time positions; a corresponding disproportionate percentage of women are employed part- time.

\section{Access to Power and Information}

There are a number of ways employees can influence and improve their individual or collective situations. An important ingredient is access to information. Those in supervisory or administrative positions have more information than those they supervise about how and why decisions are made. They also have more say in these decisions.

Ten percent of the women and sixteen percent of the men faculty members were in some administrative position in 1989-90. This reflects mostly those who are Heads of Departments or Directors of Schools. Only one woman in the university's history has ever been Dean of a faculty; she was appointed in 1982. No woman has ever served as vice president or president. The gender distribution 
within the other employee groups, already examined, documents that men dominate the higher level, supervisory positions among the non-academic staff as well.

Many of the faculty, librarians and the professional- technical workers would have access to information about the internal organization of employees described in this paper. Some of those in the professional-technical group are the ones who handle personnel files. Those in the physical plant and secretarialclerical positions are less likely to be aware of the benefits and constraints operating for different employees. For the custodial staff this may be a reflection of their education level. While most employees have some post-secondary training, either in trade school or business school, the custodial staff have, on average, completed only grade 9. One custodian who has served on the Status of Women Committee confided to me that she "could read and understand at least some of the stuff" in the status of women report. Many of her co-workers assume that such information is beyond their comprehension. Nevertheless, even supervisors or directors may not have information beyond that for their own group. It was not unusual for faculty and supervisory staff to learn about the structure and organization of the different employee groups through the status of women report.

Only those who negotiate the contracts and set the salaries for all employees get to see the overall picture. These are the senior managers, and the senior administrators (president and vice presidents). Access to these individuals, and to the Board of Governors, which formally sets the policies recommended by these administrators, is obviously a source of both information and power. The senior managers by definition report directly to a vice president or to the president. For most other employees there is a clearly delineated line of command set out, through supervisors and these senior managers. Faculty have a similar formal line of command, through their Department Heads and Deans or Directors. However, since faculty members serve on many of the decision-making bodies of the university (senate, curriculum committees, search committees for senior administrators, etc.) they have access to both information and power that are denied other employees. The small size of the university also facilitates informal access to administrators. Faculty can, and frequently do, call and meet with a vice president or the president with relatively short notice to discuss an issue, air a complaint, or lobby for a cause. What is more, faculty have three seats on the Board of Governors and one place on the powerful Executive of the Board. 
Students and administrators are the only other internal university groups with representatives on the Board. Student representatives present specific issues to the Board that are of concern to students. They tend to have little to say about other matters the Board discusses. Their influence on the Board is reduced, not only by their status as students, but also by the fact that they are elected for one-year terms while all other Board representatives serve for three years. Non-faculty employee groups have been explicitly denied access to membership on the Board.

Another potential source of both information and power can be found in the unions or organizations representing the employee groups. The "nons", by definition, have no organizing group. The professional-technical staff have "terms of employment", but no formal organization. For the past several years, since the removal of the senior managers from this group in 1989, no meetings of this group have been called; no one seems to know who would call it. The faculty, physical plant and secretarial-clerical staff all belong to formal unions.

In the survey, respondents were asked how often they attend meetings of their union or group. Less than a quarter of the eligible employees say they regularly attend these meetings. Among the faculty, women were more likely than men to say that they attended "regularly"; women were also more likely to say they attended "rarely" (men tended to say "occasionally"). Among the non-academic staff, women were less likely than men to attend union meetings "regularly" or "occasionally".

In both their terms of employment, and their access to power and information, faculty enjoy a favourable position within the university relative to other employees. Only the senior managers and senior administrators (especially the latter) could be seen as having as many (or more) benefits, flexibility and power. Women tend to be concentrated in the least powerful groups and tend to have the lowest levels of benefits within those groups, either because of their part-time status, or because of their low rank. The employees' groups and unions do not appear to have done much to rectify the powerlessness of many of the employees. Even in the woman-dominated secretarial-clerical group, most of the employees are only marginally involved in the union.

These gender differences affect various aspects of the employees' experiences. The next section will examine the effects on employee salaries and on their perceptions of how equitable the university is an employer. 


\section{Salaries}

Many employees define salary as the most important "benefit" provided for in their terms of employment. One could do a detailed analysis focusing exclusively on employee salaries, what variables affect them and how these effects differ for the different groups. This analysis will restrict itself to two issues: how faculty salaries compare to those of other employees, and how gender influences salary across and within groups.

Table 4 shows the mean and median yearly salaries (a) for all employees and (b) for full-time employees in each group. For those employees working less than a full year (such as full-time faculty with 9 month positions, as well as any part-time employees), the "yearly salary" was calculated by prorating their salary as if they were employed the full year. So, a nine month sessional's salary would be multiplied by a factor of 1.33 . This gives a false impression of how much these individuals earned, but it allows for comparisons across categories.

In Table 4 the thirteen senior managers and four senior administrators have been separated out since their salaries reflect their administrative positions, not their group affiliation (e.g., the vice-president academic and the president are technically "faculty", but their salaries are not set by the faculty union). Both the mean and the median salaries for faculty are higher than for any other nonadministrative group. One could argue that these higher salaries are warranted by the fact that faculty have higher levels of education than any other group, and/or by the claim that faculty are essential to the teaching and research goals of the university. Senior administrators and managers claim even higher salaries on the basis of the level of responsibility they bear and the unpredictable, and often lengthy hours they have to work. This unpredictability of time demands make administrative positions more problematic for those with responsibility for young children, often women.

Among the other employee groups, the "nons" stand out as having the lowest average salaries, reflecting the large number of sessional employees working at minimum wage. Women in the secretarial-clerical group, and both men and women in the physical plant have lower salaries, on average, than those in other groups. The low levels for the secretarial-clerical workers are particularly interesting, given that they have higher levels of education than most of the physical plant workers. The secretarial staff argue, with some justification, that their jobs require more responsibility than many of those in the physical plant, especially custodial workers. Custodial workers tend not to be exposed to the physically stressful demands placed on some other physical plant employees (noise, heat, 
Table 4

Mean and Median Annual Salaries for all Groups, by Gender, for A. All Employees, and B, Full-time Employees

\begin{tabular}{|c|c|c|c|c|}
\hline \multirow[b]{3}{*}{ Group } & \multicolumn{4}{|c|}{ Annual Salary } \\
\hline & \multicolumn{2}{|c|}{ Mean } & \multicolumn{2}{|c|}{ Median } \\
\hline & Men & Women & Men & Women \\
\hline \multicolumn{5}{|l|}{ A. All employees } \\
\hline Physical Plant & $\$ 18,830$ & $\$ 16,352$ & $\$ 17,156$ & $\$ 16,244$ \\
\hline Secretarial-clerical & $\$ 19,712$ & $\$ 15,484$ & $\$ 19,967$ & $\$ 15,077$ \\
\hline “Non” & $\$ 14,408$ & $\$ 10,830$ & $\$ 9.450$ & $\$ 9,458$ \\
\hline Professional \& Technical & $\$ 31,002$ & $\$ 23,643$ & $\$ 30,263$ & $\$ 22,850$ \\
\hline Librarians & $\$ 32,693$ & $\$ 26,129$ & $\$ 32,692$ & $\$ 27,642$ \\
\hline Senior Management & $\$ 47,858$ & $\mathbf{a}$ & $\$ 47,300$ & a \\
\hline Senior Administration & $\$ 79,800$ & a & $\$ 78,925$ & $\mathbf{a}$ \\
\hline Faculty & $\$ 42,498$ & $\$ 32,938$ & $\$ 44,376$ & $\$ 34,785$ \\
\hline \multicolumn{5}{|l|}{ B. Full-time Employees } \\
\hline Physical Plant & $\$ 19,200$ & $\$ 16,407$ & $\$ 17,179$ & $\$ 16,261$ \\
\hline Secretarial-clerical & $\$ 20,232$ & $\$ 15,955$ & $\$ 20,020$ & $\$ 15,574$ \\
\hline “Non" & $\$ 36,258$ & $\$ 12,864$ & $\$ 35,880$ & $\$ 10,157$ \\
\hline Professional \& Technical & $\$ 31.558$ & $\$ 24,566$ & $\$ 31,905$ & $\$ 23,390$ \\
\hline Librarians & $\$ 32,693$ & $\$ 26,126$ & $\$ 32,693$ & $\$ 27,642$ \\
\hline Senior Management & $\$ 47,858$ & $\mathbf{a}$ & $\$ 47,320$ & a \\
\hline Senior Administration & $\$ 79,800$ & a & $\$ 78,925$ & a \\
\hline Faculty & $\$ 45,298$ & $\$ 38,351$ & $\$ 45,961$ & $\$ 37,300$ \\
\hline
\end{tabular}

a No women in this category

heavy labour). Yet almost a quarter of the full-time secretarial staff make less than the lowest paid full-time custodian, even after adjusting for the different length of the work week for the two groups.

Given the different skill and education requirements for the positions among the employees, any detailed analysis of salary has to take into account the variation in pay scales for the different groups. Table 5 presents regression analyses of annual salary for five employee groups. The few librarians have equivalent levels of education, no grade or ranking system, are all full-time employees and have little variation in seniority. With only ten individuals and 
Table 5

\section{Regression Analysis of Salary by Group}

\begin{tabular}{|c|c|c|c|c|}
\hline \multirow{2}{*}{$\begin{array}{l}\text { A. Physical Plant } \\
\text { Dependent Variables: }\end{array}$} & \multicolumn{2}{|c|}{ All employees } & \multicolumn{2}{|c|}{ Full-time Employees } \\
\hline & $\mathbf{b}$ & beta & b & beta \\
\hline Education & 199.43 & .21 & 219.41 & .21 \\
\hline Years at the University & 229.66 & .38 & 228.40 & .34 \\
\hline Terms of Employmenta & -37.75 & -.01 & - & $\longrightarrow$ \\
\hline Grade & 945.65 & .15 & 938.79 & .10 \\
\hline Gender & -1711.96 & -.17 & -1798.38 & -.17 \\
\hline Constant & $15,016.86$ & - & $14,756.78$ & - \\
\hline$\underline{\mathbf{R}}^{2}$ & .32 & - & .28 & - \\
\hline B. Secretarial/Clerical & \multicolumn{2}{|c|}{ All employees } & \multicolumn{2}{|c|}{ Full-time Employees } \\
\hline Dependent Variables: & $\mathbf{b}$ & beta & $b$ & beta \\
\hline Education & 59.09 & .04 & 70.67 & .05 \\
\hline he University & 233.90 & .27 & 233.53 & .29 \\
\hline Terms of Employment ${ }^{2}$ & 1805.10 & .19 & & - \\
\hline Grade & 1435.71 & .58 & 1512.14 & .65 \\
\hline Step & 77.39 & .04 & 179.57 & .10 \\
\hline Gender & -1219.20 & -.13 & -1042.42 & -.12 \\
\hline Constant & 5492.93 & - & 7829.42 & - \\
\hline $\mathrm{R}^{2}$ & .76 & - & .87 & - \\
\hline C. Professional-Technical & \multicolumn{2}{|c|}{ All employees } & \multicolumn{2}{|c|}{ Full-time Employees } \\
\hline Dependent & b & beta & b & beta \\
\hline Education & 177.72 & .07 & 119.92 & .05 \\
\hline Years at the University & 358.92 & .27 & 229.61 & .19 \\
\hline Terms of Employment ${ }^{2}$ & 6118.40 & .31 & - & $\longrightarrow$ \\
\hline Grade & 2589.67 & .53 & 2894.52 & .69 \\
\hline Gender & -3435.70 & -.24 & -4131.46 & -.35 \\
\hline Constant & 4117.78 & - & $18,374.71$ & - \\
\hline $\mathrm{R}^{2}$ & .73 & - & .69 & - \\
\hline D. "Non" & \multicolumn{2}{|c|}{ All employees } & \multicolumn{2}{|c|}{ Full-time Employees } \\
\hline Dependent Variables: & $\mathrm{b}$ & beta & b & beta \\
\hline Education & 752.70 & .17 & 1248.16 & .19 \\
\hline Years at the University & 974.86 & .38 & 1176.91 & .43 \\
\hline Terms of Employment ${ }^{\mathrm{a}}$ & $12,050.11$ & .39 & - & $\overline{-}$ \\
\hline Gender & -747.94 & -.03 & -1245.67 & -.27 \\
\hline Constant & $-15,461.72$ & - & $14,823.01$ & - \\
\hline$\underline{\mathrm{R}^{2}}$ & .48 & $=$ & .52 & - \\
\hline a Full-time versus part-time & $\mathrm{b}^{\mathrm{ancludes} \text { senior } \mathrm{n}}$ & & (tab & tinues...) \\
\hline
\end{tabular}


Table 5 (continued)

\begin{tabular}{|c|c|c|c|c|}
\hline \multirow{2}{*}{$\begin{array}{l}\text { E. Faculty } \\
\text { Dependent Variables: }\end{array}$} & \multicolumn{2}{|c|}{ All employees } & \multicolumn{2}{|c|}{ Full-time Employees } \\
\hline & b & beta & b & beta \\
\hline Rank & 5064.95 & .46 & 5292.42 & .48 \\
\hline Years at the University & 511.57 & .39 & 515.08 & .39 \\
\hline Terms of Employmenta & 2401.13 & .12 & - & - \\
\hline Gender & -3223.58 & -.12 & -3431.96 & -.12 \\
\hline Constant & $16,970.55$ & - & $25,768.94$ & - \\
\hline $\mathrm{R}^{2}$ & .69 & - & .67 & - \\
\hline a Full-time versus part-time & $\mathrm{b}_{\text {Includes senior } \mathrm{r}}$ & & where $1=$ male, 2 & \\
\hline
\end{tabular}

so little variation, a regression analysis makes little sense. For librarians, the gender differences are reflected in the means and medians reported in Table 4.

The most important finding to note from Table 5 is that, for all employee groups, gender has a large impact (in terms of dollars and in size of effect as measured by the "betas") on employees' salaries, even after controlling for education, rank or grade, seniority and terms of employment. This gender effect is evident whether one considers all employees or just those with full-time positions. The consistency of this pattern makes it clear that within all employee groups, even when one takes into account their lower positions, women do not receive the same benefits as their male co-workers.

\section{Perceptions of Inequality}

The surveys sent to faculty and staff asked not only about their positions, but also about their perceptions of inequities in the ways men and women are treated. Table 6 shows the responses of faculty and the non-academic staff to questions about hiring, promotion, and salaries as well as whether the individual respondent had personally experienced "discrimination based on gender" or "sexual harassment" at the university. Controlling on each employee group for these detailed tables reduces the case base to the point where comparisons of percentages are meaningless, so all non-academic employees are grouped together for this section of the analysis.

Less than half the faculty and staff think there is equity in the hiring procedures. (See Table 6A.) Women are more likely than men to say men have the advantage, but few suggest women do. Overall, $15 \%$ of faculty and $10 \%$ of the non-academic staff see men having an advantage. This difference may reflect the fact that faculty have more say in hiring and may be correspondingly better 
Table 6

Perceptions of Gender Equity by Gender: Faculty and Non-Academic Employees

\section{A. Hiring}

Men Advantage

Women Advantage Equal

No Opinion

\section{B. Salaries}

Men Advantage

Women Advantage

Equal

No Opinion

\section{Promotions}

Men Advantage

Women Advantage

Equal

No Opinion
Faculty

\begin{tabular}{rcc}
\hline Men & Women & Total \\
\hline $11 \%$ & $26 \%$ & $15 \%$ \\
$4 \%$ & $2 \%$ & $4 \%$ \\
$41 \%$ & $36 \%$ & $40 \%$ \\
$43 \%$ & $36 \%$ & $41 \%$ \\
\hline
\end{tabular}

\begin{tabular}{rcc}
\hline Men & Women & Total \\
\hline $11 \%$ & $21 \%$ & $13 \%$ \\
$0 \%$ & $0 \%$ & $0 \%$ \\
$44 \%$ & $33 \%$ & $42 \%$ \\
$44 \%$ & $46 \%$ & $45 \%$ \\
\hline
\end{tabular}

\begin{tabular}{rcr}
\hline Men & Women & Total \\
\hline $8 \%$ & $19 \%$ & $10 \%$ \\
$2 \%$ & $0 \%$ & $2 \%$ \\
$68 \%$ & $43 \%$ & $62 \%$ \\
$22 \%$ & $38 \%$ & $28 \%$ \\
\hline
\end{tabular}

Non-Academic Employees

\begin{tabular}{rcr}
\hline Men & Women & Total \\
\hline $8 \%$ & $12 \%$ & $10 \%$ \\
$1 \%$ & $3 \%$ & $2 \%$ \\
$56 \%$ & $34 \%$ & $44 \%$ \\
$36 \%$ & $51 \%$ & $44 \%$ \\
\hline
\end{tabular}

\begin{tabular}{rcr}
\hline Men & Women & Total \\
\hline $8 \%$ & $21 \%$ & $15 \%$ \\
$0 \%$ & $1 \%$ & $0 \%$ \\
$57 \%$ & $31 \%$ & $43 \%$ \\
$35 \%$ & $47 \%$ & $41 \%$ \\
\hline
\end{tabular}

\begin{tabular}{rcc}
\hline Men & Women & Total \\
\hline $14 \%$ & $23 \%$ & $19 \%$ \\
$3 \%$ & $4 \%$ & $4 \%$ \\
$60 \%$ & $40 \%$ & $49 \%$ \\
$22 \%$ & $33 \%$ & $28 \%$ \\
\hline
\end{tabular}

D. Percentage who had Personal Experience with Gender Discrimination

Faculty

\begin{tabular}{cccc}
\hline Men & Women & Total & $\mathrm{n}$ \\
\hline $8 \%$ & $37 \%$ & $15 \%$ & 184
\end{tabular}

Non-Academic

Employees

\begin{tabular}{cccc}
\hline Men & Women & Total & $\mathrm{n}$ \\
\hline $7 \%$ & $15 \%$ & $11 \%$ & 221
\end{tabular}

E. Percentage who had Personal Experience with Sexual Harassment Faculty

Non-Academic Employees

\begin{tabular}{cccc}
\hline Men & Women & Total & $\mathrm{n}$ \\
\hline $11 \%$ & $38 \%$ & $17 \%$ & 182
\end{tabular}

\begin{tabular}{cccc}
\hline Men & Women & Total & $\mathrm{n}$ \\
\hline $10 \%$ & $23 \%$ & $18 \%$ & 137
\end{tabular}


informed. Or, it may reflect the fact that there are more women among the nonacademic staff. We need more detailed qualitative data from employees at a range of institutions to understand the reasons behind this kind of employee perception.

Another survey question asks about gender equity in salaries. (See Table 6B.) Despite the very large differences in salary levels, non-academic employees are as likely as faculty to say there is equity ( $42 \%$ and $43 \%)$. In both categories of employees twice as many women as men see men having an advantage.

Faculty are much more likely than the non-academic staff to see promotions as fairly dispensed (Table 6C). Sixty-two percent of faculty compared to $49 \%$ of other employees say men and women are equally likely to be promoted. For both academic and non- academic respondents, women are more likely than men to perceive the promotion process as biased in favour of men.

There are two important differences in the promotion procedures for the two groups. Decisions concerning faculty promotions are made by a committee of faculty members, elected by faculty. Promotions among the non-academic staff are decided by supervisors and administrators. Secondly, for the non-academic staff, promotions often involve a "zero sum" decision process. If one person gets a promotion to a specific higher level position it means someone else does not. There are only so many high level positions, especially ones which carry supervisory rank (and salary and benefits). For faculty there is no pre-set number of full or associate professors. Once someone is hired and tenured, there is no direct disadvantage to anyone else if this individual is promoted to a higher rank. Faculty women can be promoted without affecting the number of men also promoted. The same is not the case for the women in non-academic positions.

Overall, more than a third $(37 \%)$ of the faculty women say they have personally experienced gender discrimination (Table 6D). Not all of this discrimination reflects the actions of the university as employer, except to the extent that the university is responsible for ensuring a non-discriminatory working environment. It is often a reflection of the actions of other employees. Women tell of their research being down-played, their suggestions in committees ignored, their applications for promotion not supported. The official records show that women spend longer in rank than men, and are less likely to put themselves up for promotion; but once they do, they are more likely to be promoted. In their descriptions of the process, it is clear that many women feel the cards are stacked against them, so they wait until their credentials are even stronger than those of their men colleagues who get promoted sooner. 
Women in the non-academic staff report more discrimination than their male co-workers (15\% versus $7 \%$ ). Given the gender segregation of many of the jobs (men in physical plant, women as secretaries and clerks), they know mostly their own situation relative to others of the same gender. Secretaries recognize they are poorly paid, but rarely see this as a gender issue, since most secretaries they know, both in the university and outside, make similarly low salaries.

What is perhaps surprising in these questions about gender discrimination is how many employees say they "don't know" or have "no opinion" about these matters. These are employees who took the time to respond to a seven to nine page questionnaire distributed by the Status of Women Committee. Presumably the non-respondents were even less interested in these issues. Those who wish to change the structures that create inequities will first have to make employees as well as employers aware of the extent of the problem.

A final question in the surveys dealt with sexual harassment. (See Table 6E.) Again more women than men report having personally experienced harassment $(38 \%$ versus $11 \%$ among the faculty, and $23 \%$ versus $10 \%$ among the non-academic staff). Both faculty and staff report a range of harassments ranging from verbal comments to unwanted touching and explicit sexual advances. While women faculty report proportionately more of these incidents, non-academic employees are often more vulnerable, especially if the "harasser" is one's supervisor. Probationary employees among the non-academic staff are the most vulnerable of all. The formal and informal terms of employment for the nonacademic employees explicitly state that there can be no challenge or appeal if a probationary employee is dismissed or disciplined. Since they rely so heavily on an acceptable rating from their supervisors, probationary employees are in no position to resist advances from those in positions of power.

\section{Conclusion}

This paper has examined information from one small university in the Atlantic region of Canada. These data allow a comparison between faculty and non-academic staff, and between men and women within categories of employees. Several status of women studies have documented the gender discrimination faced by faculty at different Canadian universities. This analysis has shown that men and women faculty have more benefits, higher salaries and better working conditions than their non-academic colleagues, with the possible exception of those who have made their way into administration.

Women in the non-academic sector are doubly disadvantaged. They tend to be in the lower paid, more restricted secretarial-clerical positions. Regardless of 
the employee group in which they find themselves, they are at the low end of the wage and benefit continuum.

The consistency of the gender difference within and across employee groups is striking. Women are paid less, have less access to promotions, have less say in the decision-making process at the university than do men. The "employee groups" that influence policy are the administrators, the managers, and, to a lesser extent, the faculty. There are no women in the senior administration, none as senior managers, and only one Dean. Women are a minority in the faculty and are concentrated at the lower, less influential ranks.

These employees all have the same employer. The same Board of Governors sets the policies, negotiates the contracts, makes the administrative appointments. What is more, the money for salaries and other benefits, such as paid leaves, for all employees comes from the same pot. Advantages that faculty have been able to negotiate may well be at the expense of the non-academic support staff.

If gender equity is to be achieved by university faculty it will require a change in the structures that allow inequities to develop and persist, as well as a change in attitude by those who set policies. It is to be hoped that a change in attitude would benefit all employees, academic and non-academic alike. Those who propose equity structures should be careful that the provisions of this structure create a fair working environment for all employees, not just the highly visible faculty.

\section{References}

Ad Hoc Committee On the Status of Women at U.B.C. (1984). Academic women at the University of British Columbia, 1972-82. Vancouver: Author.

Alsenberg, N., \& Harrington, M. (1988). Women of acadente: Outsiders in the sacred grove. Amherst: University of Massachusettes Press.

Baar, E., Drummond, R., Fox; J., Greenglass, E., Hoffmann, E., \& Stewart, J. (1988). Report of the Joint Implementation Committee of Affirmative Action for Women Faculty. Toronto: York University.

Backhouse, C. (1988). Women faculty at University of Western Ontario: Reflections on the employment equity award. London, Ontario: University of Western Ontario.

Backhouse, C., Harris, R., Mitchell, G., \& Wylie, A. (1989). The chilly climate for faculty women at University of Western Ontario: Postscript to the Backhouse report. University of Western Ontario.

Breslauer, H. (1985). Women in the professoriate. The professoriate - occupation in crisis. Toronto: O.I.S.E, 82-104. 
Breslauer, H., \& Gordon, J. (1989). The two gender university: Catching up to changes in the clientele. Paper presented at the meeting of the Canadian Sociology and Anthropology Association, and the Canadian Society for the Study of Higher Education, Laval, Quebec.

Dalhousie Committee on the Status of Women, (1979). Report of the Committee on the Status of Women. University News, Dalhousie University, Special Edition, January.

Dagg, A.I. \& Thompson, P.J. (1988). Miseducation: Women at Canadian universities. Toronto: O.I.S.E.

Denton, M., Ahmed, M., Howard, R., \& Zeytinoglu, I. (1989). Integration of female faculty at McMaster University. Hamilton: McMaster University.

Groarke, L. (1983). Beyond affirmative action. Allantis, 9(1), 13-24.

Hall, R., \& Sandler, B. (1983). Academic mentoring for women students and faculty. Washington, DC: Association of American Colleges.

Laurentian University. (1980). Report of the Status of Women Committee, 1979-80. Sudbury: Author.

Looker, D. (1990). The marginal majority: A report to the president on the status of women at Acadia. Wolfville: Acadia University.

Lundy, K.L.P., \& Warme, B.D. (1986). Part-time faculty: Institutional need and career dilemma, In K.L.P. Lundy and B.D. Warme, Work in the Canadian context. Toronto: Butterworths.

McIntyre, \& Doherty, J. (1975). Women in Ontario universities: A report to the Ministry of Colleges and Universities. Toronto.

McMillan, M. (1985). How affirmative action programs fail women in non-traditional jobs. Canadian Women Studies, 6(4), 46-48.

Meinake, P. (1974). Report of the Committee on employment conditions of full-time women faculty. Toronto: University of Toronto.

O.C.U.F.A. Status of Women Committee. (1986). Employment equity for women academics: A positive action strategy. O.C.U.F.A.

Queen's University. (1972). Report of the principal's conmittee on the stalus of women. Kingston: Author.

Committee on the Status of Women. (1978). Report of the committee on the status of women at Acadia University. Acadia: Author.

Simeone, A. (1987). Academic women working towards equality. South Hadley, Mass: Bergin and Garvey.

Swartz, S. (1976). Things do happen in the groves of academe. Branching Out, 4, 6-10.

Thibault, G.M. (1987). The dissenting feminist academy, $A$ history of the barriers to feminist scholarship. New York: Peter Lange.

Tomm,W., \& Hamilton, G. (Eds.). (1988). Gender bias in scholarship. Waterloo: Wilfred Laurier University Press.

University of British Columbia. (1973). Final report on the President's ad hoc committee which considered 'A Report on the Status of Wonten at the U.B.C.', with particular reference to employed staff. Vancouver: U.B.C.

University of Waterloo. (1973). Report of the President's advisory committee on equal rights for women and men. Waterloo: Author. 
University of Windsor. (1974). Report of the faculty association sub-committee on the status of women academics. Windsor: Author.

Vickers, J., \& Adam, J. (1977). But can you type? Canadian universities and the status of women. Toronto: Clarke, Irwin and Company.

York University. (1985). Status of women report. Toronto: Author. 